\title{
Corruption and Economic Growth: A South Korean Study
}

\author{
Chong-Uk Kim ${ }^{1}$ and Gieyoung Lim²,
}

${ }^{1}$ Dept. of Economics, Sonoma State University, 1801 E. Cotati Ave, Rohnert Park, CA 94928, USA

${ }^{2}$ Dept. of International Economics \& Law, Hankuk University of Foreign Studies, 107 Imunro, Dongdaemungu, Seoul, 130-791, Korea

\begin{abstract}
Using a vector autoregressive model (VAR) with 42 years of South Korean annual data, we empirically investigate two possible links between corruption and economic growth. Even though we find negative correlations between corruption and other growth variables such as private investment, we do not find any strong empirical evidence supporting negative correlations between corruption and economic growth. Our results are similar to previous empirical findings and seem to be another empirical mismatch between micro and macro level data.
\end{abstract}

Keywords: Economic Growth, Corruption, Private Investment, Vector Autoregressive Model.

\section{INTRODUCTION}

Mr. Kim's father used to run a small manufacturing company producing electrical products such as electric blanket, electric stove, and electric pot in Korea. He had managed his company very well for almost 30 years and retired successfully. When Mr. Kim was a college student, he used to help his father's business during summer vacation. Since he was a naive young man, sometimes he did not understand the way that his father was running his business. His father was a very meticulous person and always went through the allnecessary formalities. Surprisingly, however, when he met public service workers, he paid money for their public service even though he did not need to at all. The money which his father gave to public servants looked like another tax to Mr. Kim. His father, however, called it a lubricant.

Just like his father's story above, there are two different theoretical assessments on corruption and its relationship with economic outcome. One group of researchers suggests that corruption might have a positive effect on economic outcome or growth (Leff (1964), Huntington, (1968), Lui (1985), and Acemoglu \& Verdier (1998)). Like his father's idea, these previous research efforts consider corruption as a lubricant that allows firms to move faster and is able to increase the growth rate of a country.

On the other hand, another group of researchers thinks that corruption acts just like any other rentseeking behaviors (Murphy, Shleifer, and Vishny (1991, 1993), Svensson (2003)). Since corruption is a rentseeking behavior, it reduces the efficiency of an

*Address correspondence to this author at the Dept. of International Economics \& Law, Hankuk University of Foreign Studies, 107 Imunro, Dongdaemungu, Seoul, 130-791, Korea; Tel: 82-2-2173-3207; E-mail: gylim@hufs.ac.kr economy and eventually slows down the growth rate of a country.

Empirical findings seem to support the second perspective. Especially empirical works on micro level or case studies tend to show the negative relationship between corruption and economic outcome (Bates (1981), De Soto (1989), Svensson (2003), Khwaja and Mian (2004)). However, empirical studies on macrolevel data have not found the robust evidence of a connection between corruption and economic growth. Since a well-known Mauro's paper in 1995, macro-level empirical studies have tried to test the link between corruption and economic growth through the private investment channel. So to speak, corruption tends to lower private investment first, because once bribery works in a society, producers pay more bribes to generate higher profits. Just like any other rent-seeking activities, therefore, corruption reduces firms' productive investments and lowers countries' private investment in the long run. Finally, corruption reduces the growth rate of a country.

One subject of absorbing interest here is that Mauro (1995) does not find any empirical correlation between corruption and economic growth, while he finds empirical evidence that corruption is significantly lowering private investment. Based on Mauro (1995), Svensson (2005) updates Mauro's study and runs multiple regressions to test the hypothesis between corruption and economic growth but his study generates statistically insignificant results. ${ }^{1}$

${ }^{1}$ On the other hand, based on Mauro (1995), Mo (2001) finds that corruption has a negative effect on private investment and this corruption-investment link explains about $28 \%$ of the growth rate reduction in his corruption-growth equation. However, Mo's empirical findings suffer from his country selection process and the small number of observations. 
Based on these interesting previous research efforts, we try to test this corruption-growth hypothesis with an alternative econometric method which is a vector autoregressive model (VAR). There are three reasons why we choose to use a VAR to find macrolevel empirical evidence supporting the corruptiongrowth hypothesis. First, since corruption affects firms' business activities continuously over a long period of time, it is reasonable to consider that corruption also affects the growth rate of a country over time. Second, Mauro (1995) uses cross-section regression models with economic growth over the period 1970-1985, but cross-section models are limited to capture dynamics over a long period of time. ${ }^{2}$ Third, a VAR is the best way to capture the linear interdependencies among multiple time series.

Using a VAR with 42 years of South Korean annual data, we empirically investigate two possible links between corruption and economic growth. Even though we find negative correlations between corruption and other growth variables such as private investment, we do not find any strong empirical evidence supporting negative correlations between corruption and economic growth. Our results are similar to previous empirical findings and seem to be another empirical mismatch between micro and macro level data.

\section{DATA}

\subsection{Data Description}

Supreme Prosecutors' Office of South Korea annually publishes a book named Analytical Report on Crimes. The purpose of this book is to show annual statistics of all domestic crimes and analyze criminal acts. Our data on corruption (Corruption) are drawn from these annual reports. This corruption variable contains criminal acts by government officials such as delinquency, misfeasance, and bribery from 1970 to 2011.

During our 42 years of sample period, criminal acts by government employees occur, on average, 1,543.71 times per year. Meanwhile the number of private property crimes (Property) such as theft and fraud is, on average, 265,311.6 times annually. Since Korean population increases from 31.4 million to 48.4 million during our sample period, we deflate and adjust

${ }^{2}$ Svensson (2005) runs regressions with economic growth over the period 1980-2000.
Corruption and Property variables by the number of Korean population each year. As a result, we have a variable representing the number of corruption crimes per 100,000 people (Ratio) and a variable standing for the number of private property crimes per 100,000 people (Pratio). Figures $\mathbf{1}$ and $\mathbf{2}$ provide comparisons between public corruption crimes and private property crimes of South Korea from 1970 to $2011 .^{3}$

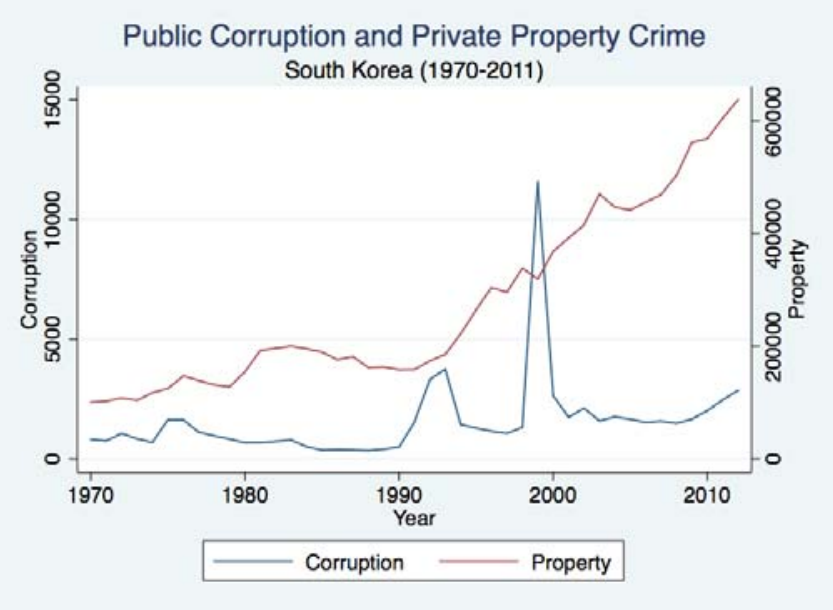

Figure 1: Public Corruption and Private Property Crime.

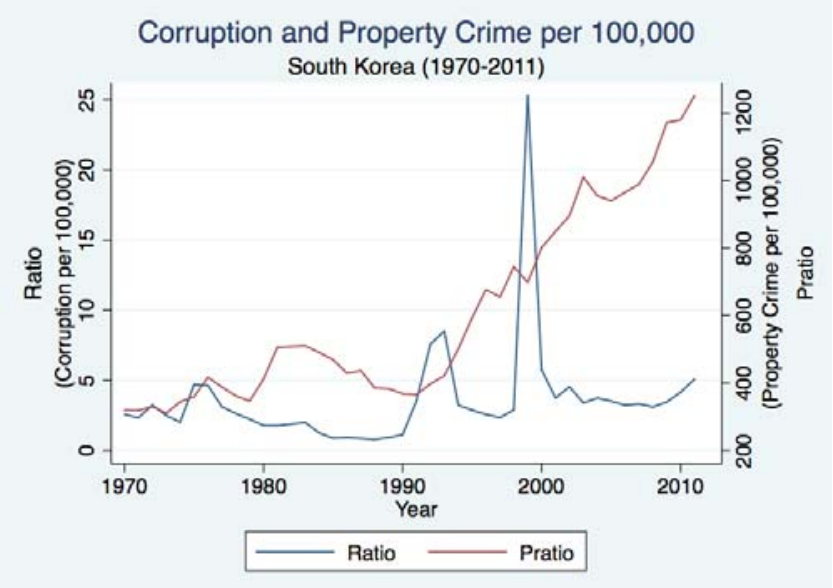

Figure 2: Corruption and Property Crime per 100,000 People.

During our sample period, South Korean GDP grows $7.3 \%$ annually. In the year of 1973 , South Korean GDP growth rate reaches the highest point, $14.8 \%$, and slows down over our sample period. South Korean GDP grow negatively twice during our sample

${ }^{3}$ As it is shown in these graphs, the Corruption (also Ratio) variable has an outlier. In the year of 1999, the number of corruption crimes reaches 11,568 and this number is 7.5 times more than the sample average. To remove any possible problems from an outlier and also to keep the time continuity, we replace this observation with the sample mean value which is 1,544 . 
period. In 1980, due to a global oil shock, the Korean economy grows negatively and it hits bottom, $-5.7 \%$, in 1998 because of Asian Financial Crisis. Figure 3 shows GDP growth rates of South Korea from 1970 to 2011.

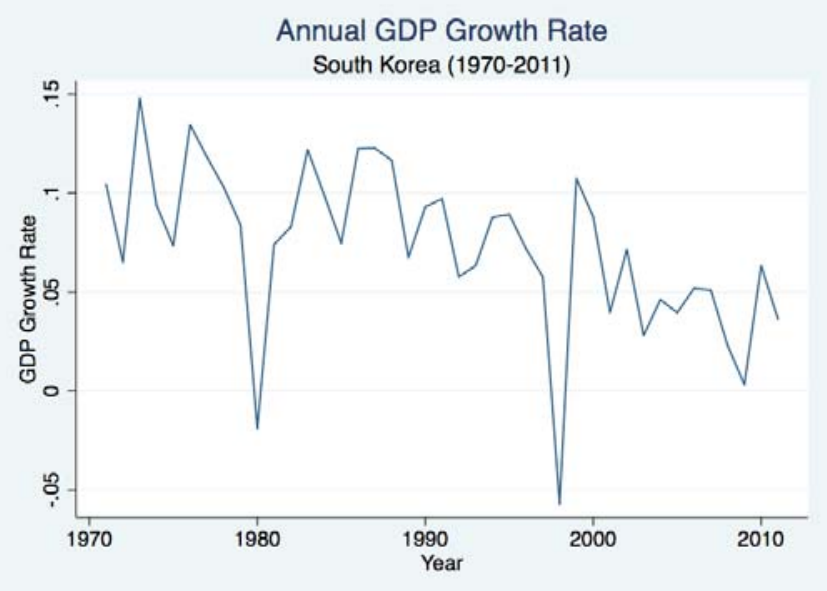

Figure 3: Annual GDP Growth Rate.

Except Corruption and Property variables, all variables used in our empirical model such as GDP growth rate (Growth), investment-output ratio $(I O)$, and total factor productivity (TFP) are available in Penn World Table version 8.0. All estimates presented in this study are based on annual South Korean data from 1970 to 2011 . The summary statistics for all variables are given in Table 1.

\subsection{VAR and Data Analysis}

The main purpose of this study is to find empirical evidence supporting the theoretical negative correlation between corruption and economic growth. Because all four variables that we need to use in our model are endogenous variables, we use a VAR model to examine their interactions. We consider two column vectors of three variables and set a VAR model per each vector.

Since our variables are all non-stationary and there is no cointegration, we transform our variables to percentage change variables. For example, our Corruption variable is transformed to corr which represents the annual percentage change of corruption crimes. Similarly, ioratio variable stands for the annual percentage change of investment-output ratio and $f p$ variable represents the annual percentage change of TFP. In addition, grate variable representing the annual percentage change of GDP growth rate replaces Growth variable. Table 2 presents the summary statistics for all four annual percentage change variables.

Table 3 shows test statistics from Phillips-Perron test for unit roots. It clearly indicates that we can reject the null hypothesis of a unit root for all four variables at the 1 percent level of significance. Since all four variables are stationary, we build two column vectors

Table 1: Summary Statistics

\begin{tabular}{|c|c|c|c|c|c|}
\hline Variable & Obs & Mean & Std. Dev. & Min & Max \\
\hline Year & 42 & 1990.5 & 12.27 & 1970 & 2011 \\
\hline Corruption & 42 & 1543.71 & 1760.83 & 342 & 11568 \\
\hline Property & 42 & 265311.6 & 149914.8 & 100592 & 605360 \\
\hline Ratio & 42 & 3.59 & 3.81 & .81 & 25.28 \\
\hline Pratio & 42 & 607.59 & 282.69 & 311.15 & 1250.97 \\
\hline 10 & 42 & .32 & .04 & .21 & .41 \\
\hline TFP & 42 & .86 & .13 & .61 & 1.04 \\
\hline Growth & 41 & .073 & .041 & -.057 & .148 \\
\hline
\end{tabular}

Table 2: Summary Statistics for VAR Variables

\begin{tabular}{|c|c|c|c|c|c|}
\hline Variable & Obs & Mean & Std. Dev. & Min & Max \\
\hline \hline corr & 41 & 9.04 & 49.84 & -61.75 & 210.35 \\
\hline ioratio & 41 & .85 & 8.82 & -25.95 & 20.26 \\
\hline$f p$ & 41 & 1.28 & 2.70 & -6.70 & -491.58 \\
\hline grate & 41 & -29.29 & 104.92 & 127.12 \\
\hline
\end{tabular}


Table 3: Phillips-Perron Test for Unit Root

\begin{tabular}{|c|c|c|c|c|c|}
\hline Variable & Test Statistics Z(t) & p-Value for Z(t) & $\mathbf{1 \%}$ Critical Value & $\mathbf{5 \%}$ Critical Value & $\begin{array}{c}\mathbf{1 0} \% \text { Critical } \\
\text { Value }\end{array}$ \\
\hline \hline grate & -4.915 & 0.0000 & -18.016 & -12.884 & -10.440 \\
\hline$f p$ & -5.781 & 0.0000 & -18.084 & -12.916 & -10.460 \\
\hline ioratio & -5.237 & 0.0000 & -18.084 & -12.916 & -10.460 \\
\hline corr & -4.832 & 0.0000 & -18.084 & -12.916 & -10.460 \\
\hline
\end{tabular}

and set a VAR model per each column vector to test our main hypotheses.

Our first column vector includes corr, ioratio, and grate, $\mathrm{Y}_{1^{\prime} \mathrm{t}}=\left[\right.$ corr $_{\mathrm{t}}$ ioratio $_{\mathrm{t}}$ grate $\left._{\mathrm{t}}\right]$, and the second column vector contains corr, fp, and grate, $\mathrm{Y}_{2}{ }_{\mathrm{t}} \mathrm{t}=\left[\right.$ corr $_{\mathrm{t}}$ $f p_{\mathrm{t}}$ grate $_{\mathrm{t}}$. Hence, our VAR(2) models can be written as

$Y_{1, t}=m+\Phi_{1} Y_{1, t-1}+\Phi_{2} Y_{1, t-2}+\varepsilon_{t}$

$\mathrm{Y}_{2, \mathrm{t}}=\mathrm{m}+\Phi_{1} \mathrm{Y}_{2, \mathrm{t}-1}+\Phi_{2} \mathrm{Y}_{2, \mathrm{t}-2}+\varepsilon_{\mathrm{t}}$

Figures 4 to 7 provide graphical information on four variables in our VAR models.

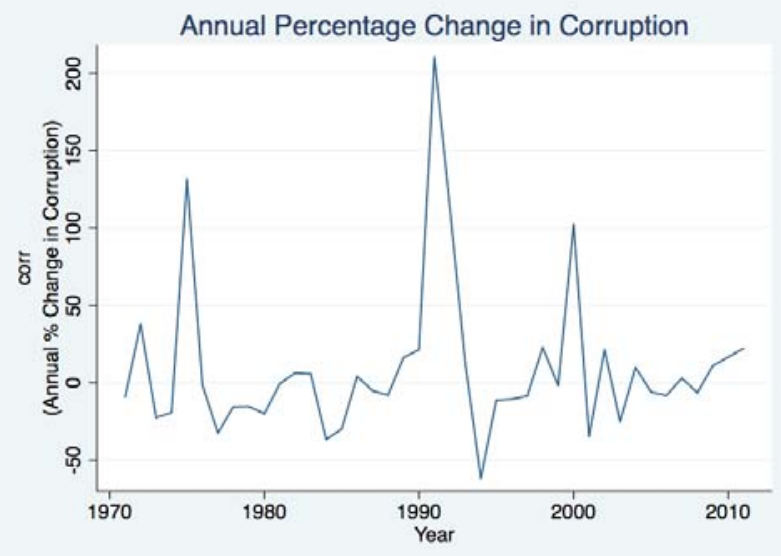

Figure 4: Annual Percentage Change in Corruption.

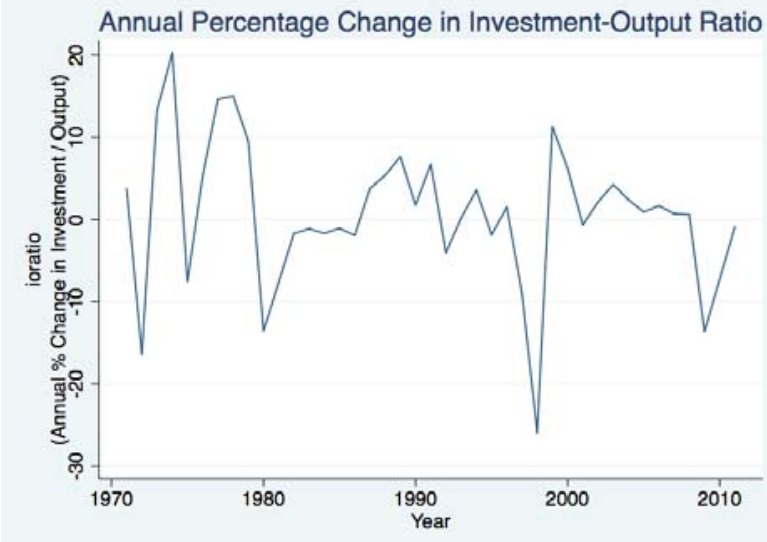

Figure 5: Annual Percentage Change in Investment-Output Ratio.

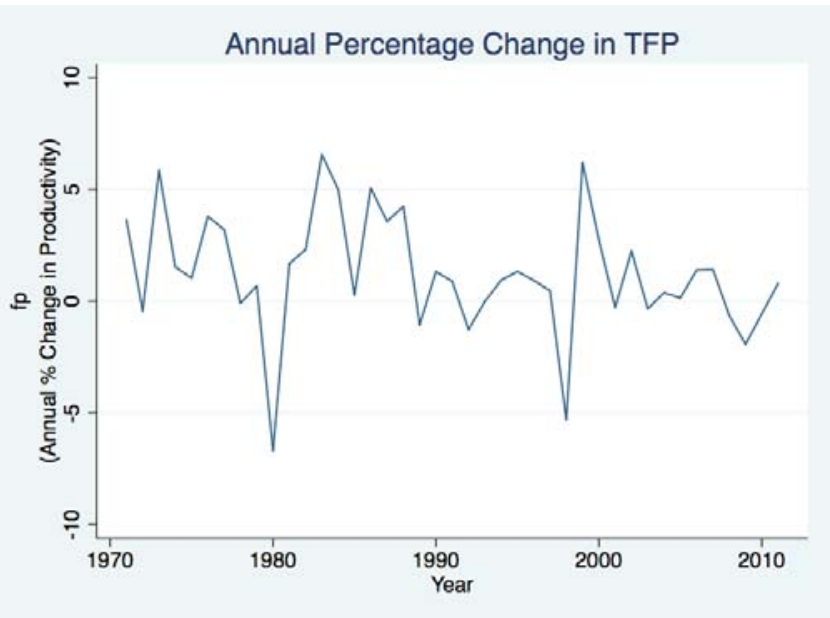

Figure 6: Annual Percentage Change in TFP.

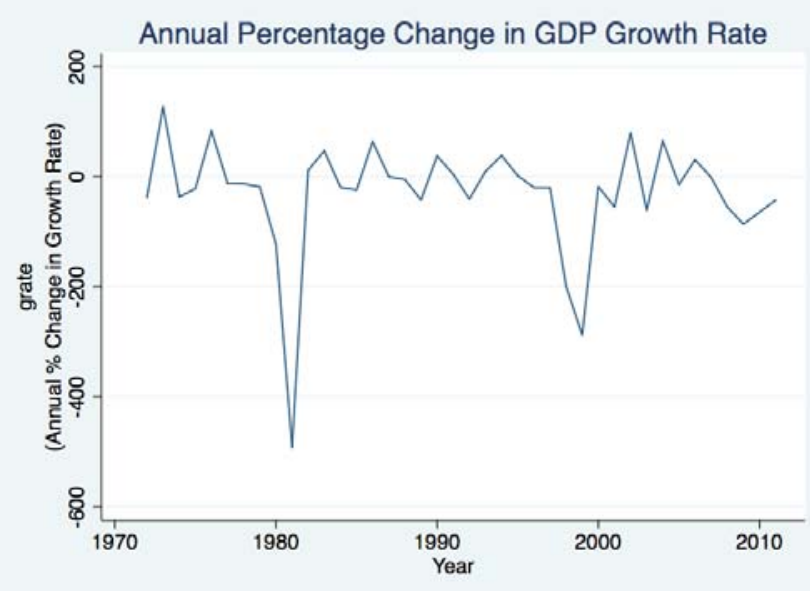

Figure 7: Annual Percentage Change in GDP Growth Rate.

\section{EMPIRICAL RESULTS}

\subsection{Pairwise Correlations}

This section provides information on correlation coefficients between corr variable and other variables. The pairwise correlation coefficient between corr variable and ioratio variable, as expected, is negative. This negative correlation implies that higher corruption lowers private investment, which accords with previous empirical findings such as Mauro (1995) and Mo 
(2001). Although the magnitude is small, the correlation coefficient between corr and $f p$ variables is also negative, which supports the theoretical prediction. However, the correlation between corr and grate turns out a very small positive number, 0.0135 , and it means that there is no direct statistical evidence supporting any negative correlations between corruption crimes and economic growth.

Considering previous empirical research efforts, these results draw our interest. Previous studies using macro-level data such as Mauro (1995) and Svensson (2005) find no empirical evidence which corruption reduces economic growth directly even though they find negative correlations between corruption and other growth variables such as private investment. Figures 8 to $\mathbf{1 0}$ and Table $\mathbf{4}$ display pairwise correlations of corr and other variables.

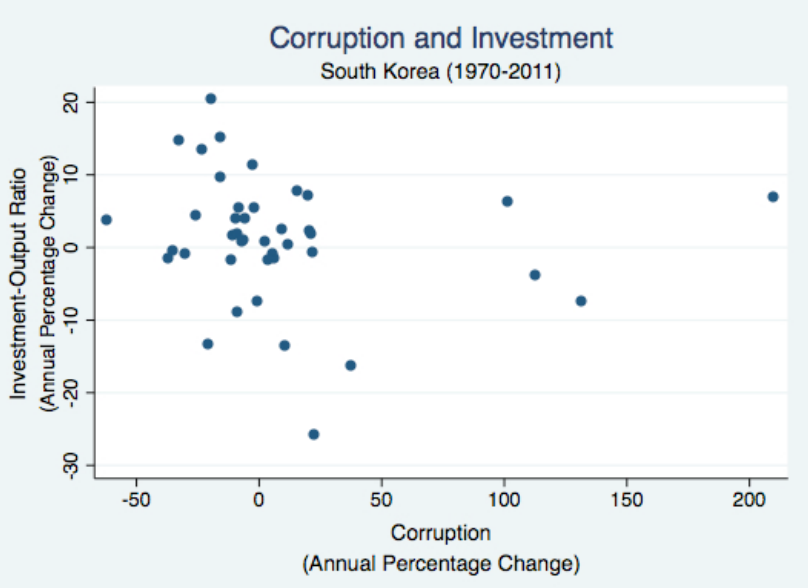

Figure 8: Corruption and Investment.

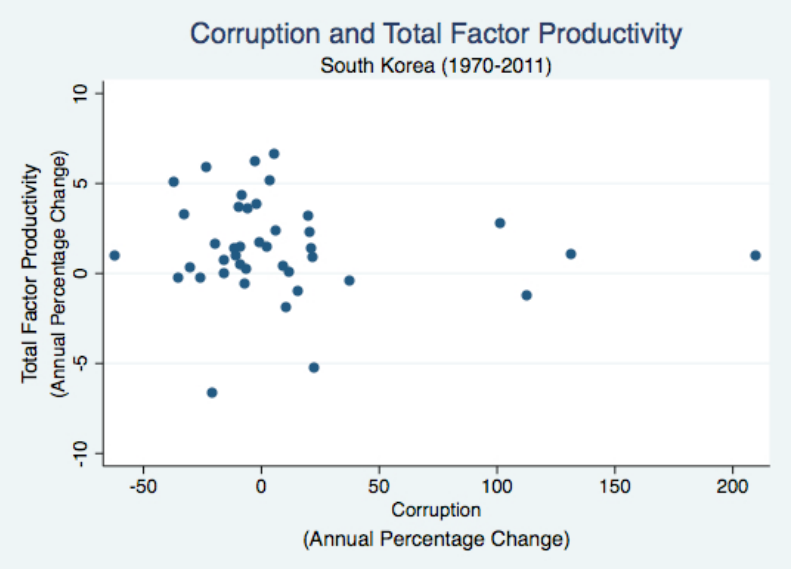

Figure 9: Corruption and TFP.

\subsection{Impulse Response}

Using the equation (1), we create impulse response functions. Figure $\mathbf{1 1}$ shows the response of corr,

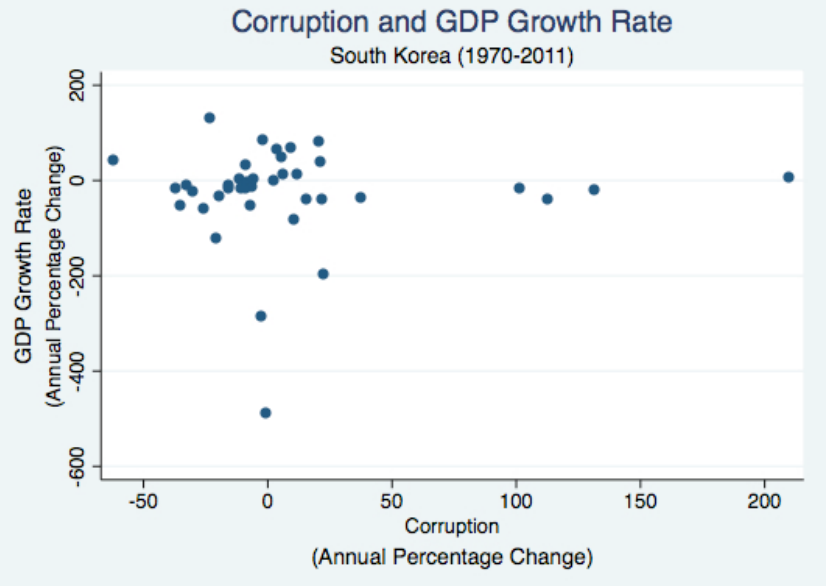

Figure 10: Corruption and GDP Growth Rate.

Table 4: Pairwise Correlations

\begin{tabular}{|c|c|}
\hline & corr \\
\hline \hline ioratio & -0.1367 \\
\hline$f p$ & -0.0949 \\
\hline grate & 0.0135 \\
\hline
\end{tabular}

ioratio, and grate variables to shocks in each variable. In the first column - the dynamic response of corr to a shock to each endogenous variable, corr responds to a shock in ioratio variable but it is not statistically significantly different from zero. In the second column, grate responds positively to a shock in iorate and it is statistically significant. This finding confirms that wellknown positive correlations between the share of investment in GDP and GDP growth rate. ${ }^{4}$ The ioratio variable, in the third column, responds positively to a shock to itself but dies out quickly. In summary, we find that the investment-output ratio affects GDP growth rate but there is no empirical evidence that corruption reduces GDP growth rate.

Our equation (2) brings us another set of impulse response functions. Figure 12 displays the results. In short, GDP growth rate responds positively to a shock in total factor productivity. Corruption also responds to a shock in total factor productivity but it is not statistically significant. Overall, we do not find evidence supporting negative correlations between corruption and economic growth.

The results from our two impulse response functions indicate that GDP growth rate responds

${ }^{4}$ For example, Levine and Renelt (1992). 


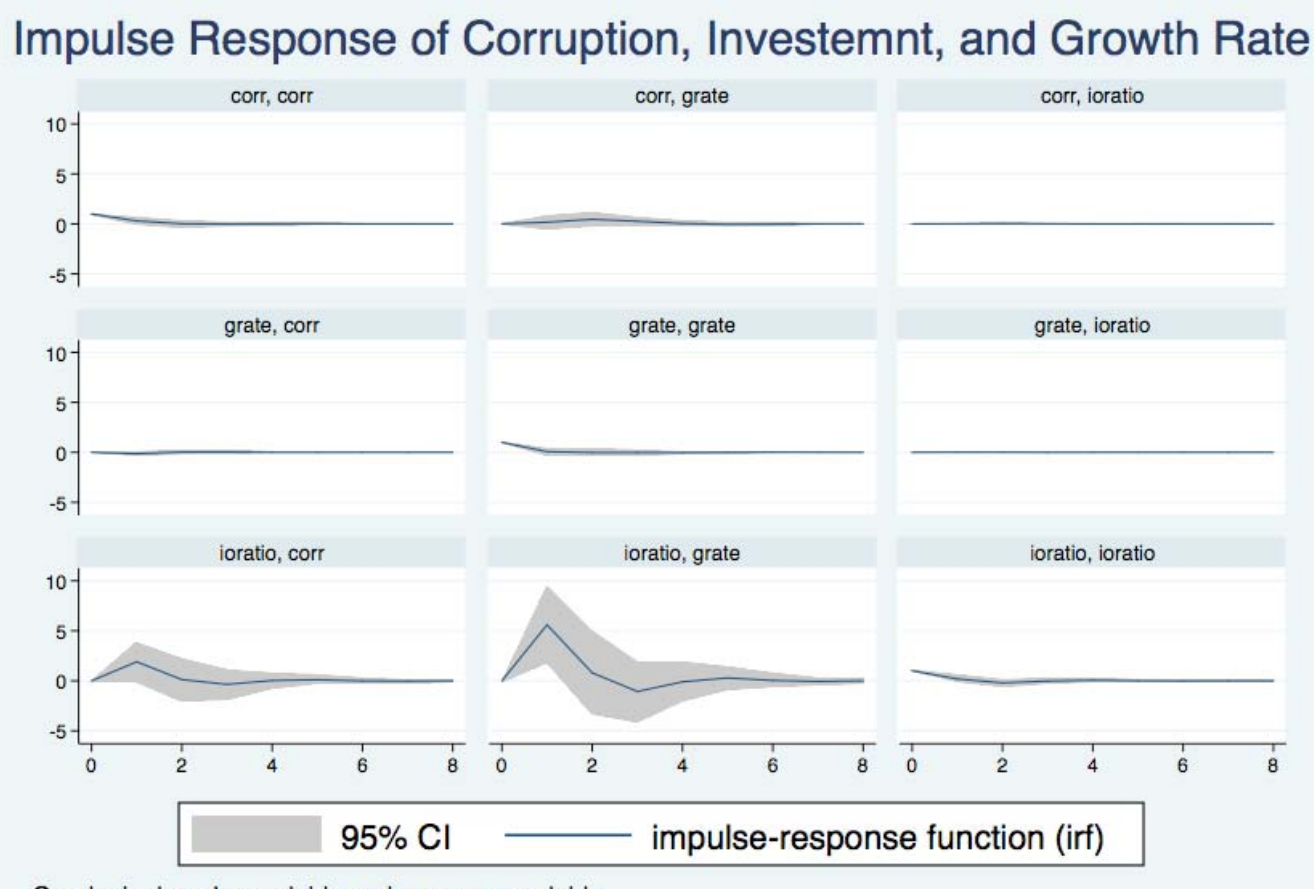

Graphs by impulse variable and response variable

Figure 11: IRF of Corruption, Investment, and Growth Rate.

\section{Impulse Response of Corruption, Productivity, and Growth Rate}

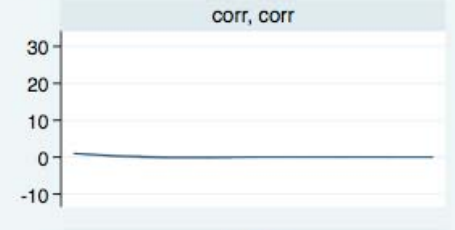

corr, tp

corr, grate

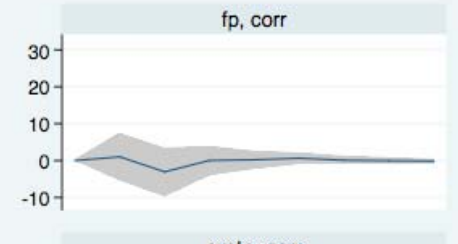

$f p, f p$

fp, grate

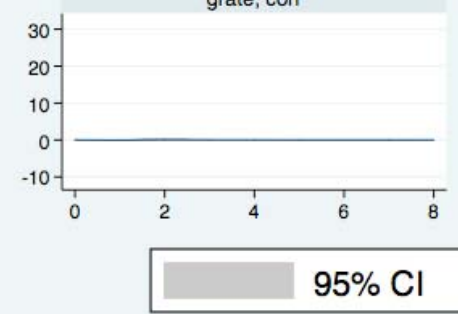

grate, fp

grate, grate

Graphs by impulse variable and response variable

Figure 12: IRF of Corruption, Productivity, and Growth Rate.

positively to a shock in the share of investment in GDP and in total factor productivity. Statistically, in addition, our corruption variable seems to have no interdependency with GDP growth rate.

\section{CONCLUDING REMARKS}

As far as we are aware, this is the first study to use

a VAR model with macro-level data to study 
correlations between corruption and economic growth. Using South Korean annual data from 1970 to 2011, we empirically investigate two possible links between corruption and economic growth. We find no empirical evidence supporting negative correlations between corruption and economic growth.

Based on previous theoretical studies and empirical research efforts with micro-level data, our finding remains a puzzle. Even though our VAR model does not contains all growth related variables, our model presents that investment-output ratio and total factor productivity play important roles in economic growth, which is consistent with previous findings. With these growth variables, however, our corruption variable does not generate any significant results, which is hard to digest. Our empirical results may suffer from our simplification of using only three major growth variables or suffer from unique South Korean growth experiences. In particular, the lack of other core growth variables such as education and political stability could be a reason for our current empirical results. Therefore, it is necessary to consider the interactions between these potential omitted variables and current existing variables in this paper, which is a topic for further study.

\section{ACKNOWLEDGEMENTS}

We thank seminar participants in 89th Annual Conference of Western Economic Association International for their helpful comments and suggestions. This was supported by Hankuk University of Foreign Studies Research Fund.
Bates, R. H. (1981) Markets and States in Tropical Africa: The Political Basis of Agricultural Policy. Berkeley: University of California Press.

De Soto, H. (1989) The Other Path. New York: Harper and Row.

Groningen Growth and Development Center. Penn World Table version 8.0. http://www.rug.nl/research/ggdc/data/pennworld-table

Huntington, S. (1968) Political Order in Changing Societies. New Haven: Yale University Press

Khwaja, A. I., and Mian, A. (2004) "Do Lenders Favor Politically Connected Firms? Rent Provision in an Emerging Financia Market." Manuscript, Kennedy School of Government, Harvard University.

Leff, N. H. (1964) "Economic Development through Bureaucratic Corruption." American Behavioral Scientist, 82:2, pp. 337-41.

Levine, R., and Renelt, D. (1992) "A Sensitivity Analysis of CrossCountry Growth Regressions." American Economic Review, 82:4, pp. 942-963.

Lui, F. T. (1985) "A Equilibrium Queuing Model of Bribery." Journal of Political Economy, 93:4, pp. 760-81. http://dx.doi.org/10.1086/261329

Mauro, P. (1995) "Corruption and Growth." Quarterly Journal of Economics, 110, pp. 681-712. http://dx.doi.org/10.2307/2946696

Mo, P. H. (2001) "Corruption and Economic Growth." Journal of Comparative Economics, 29, pp. 66-79. http://dx.doi.org/10.1006/jcec.2000.1703

Murphy, K., Shleifer, A. and Vishny, R. (1991) "The Allocation of Talent: Implications for Growth." Quarterly Journal of Economics, 106, pp. 503-30. http://dx.doi.org/10.2307/2937945

Murphy, K., Shleifer, A and Vishny, R. (1993) "Why is Rent-seeking so Costly to Growth?" American Economic Review, 83:2, pp. 409-14.

Supreme Prosecutors' Office. (1971-2012) Analytical Report on Crimes. Seoul

Svensson, J. (2003) "Who Must Pay Bribes and How Much?" Quarterly Journal of Economics, 118:1, pp. 207-30. http://dx.doi.org/10.1162/00335530360535180

Svensson, J. (2005) "Eight Questions about Corruption." Journal of Economic Perspectives, 19:3, pp. 19-42. http://dx.doi.org/10.1257/089533005774357860

\section{REFERENCES}

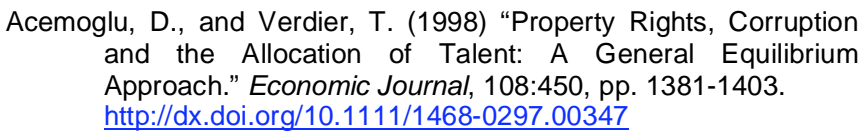

Received on 03-12-2014

Accepted on 26-01-2015

Published on 06-02-2015

DOI: http://dx.doi.org/10.6000/1929-7092.2015.04.01

(c) 2015 Kim and Lim; Licensee Lifescience Global.

This is an open access article licensed under the terms of the Creative Commons Attribution Non-Commercial License (http://creativecommons.org/licenses/by-nc/3.0/) which permits unrestricted, non-commercial use, distribution and reproduction in any medium, provided the work is properly cited. 